\title{
Effects of Monocular Deprivation on the Dendritic Features of Retinal Ganglion Cells
}

\author{
Efectos de la Privación Monocular sobre las Características \\ Dendríticas de las Células Ganglionares de la Retina
}

Philip Mwachaka*; Hassan Saidi*; Paul Odula* \& Pamela Mandela*

MWACHAKA, P.; SAIDI, H.; ODULA, P. \& MANDELA, P. Effects of monocular deprivation on the dendritic features of retinal ganglion cells. Int. J. Morphol., 32(4):1144-1151, 2014.

SUMMARY: Monocular deprivation results in anatomical changes in the visual cortex in favor of the non-deprived eye. Although the retina forms part of the visual pathway, there is scarcity of data on the effect of monocular deprivation on its structure. The objective of this study was to describe the effects of monocular deprivation on the retinal ganglion cell dendritic features. The study design was quasi-experimental. 30 rabbits (18 experimental, 12 controls) were examined. Monocular deprivation was achieved through unilateral lid suture in the experimental animals. The rabbits were observed for three weeks. Each week, 6 experimental and 3 control animals were euthanized, their retina harvested and processed for light microscopy. Photomicrographs of the retina were taken using a digital camera then entered into FIJI software for analysis. The number of primary branches, terminal branches and dendritic field area among the non-deprived eyes increased by $66.7 \%(\mathrm{p}=0.385), 400 \%(\mathrm{p}=0.002)$, and $88.4 \%(\mathrm{p}=0.523)$ respectively. Non-deprived eyes had $114.3 \%$ more terminal dendrites $(\mathrm{p}=0.002)$ compared to controls. Among deprived eyes, all variables measured had a gradual rise in the first two weeks followed by decline with further deprivation. There were no statistically significant differences noted between the deprived and control eyes. Monocular deprivation results in increase in synaptic contacts in the non-deprived eye, with reciprocal changes occurring in the deprived eye.

KEY WORDS: Monocular deprivation; Retina; Retinal Ganglion Cells; Dendritic features; Eye.

\section{INTRODUCTION}

Neuroplasticity is the ability of the nervous system to adapt its structural organization to new situations emerging from changes to intrinsic or extrinsic inputs (Antonini \& Stryker, 1993; Antonini et al., 1999). Monocular eyelid suture results in anatomical changes in the visual cortex in favor of the non-deprived eye (Wiesel \& Hubel, 1965; Tagawa et al., 2005; Cang et al., 2005; Hofer et al., 2006; Lehmann \& Löwel, 2008). This phenomenon is referred to as ocular dominance plasticity. The changes range from synaptic modifications to changes in the cell densities of the neurons in the primary visual cortex (Antonini \& Stryker; Antonini et al.; Trachtenberg \& Stryker, 2001). The structural changes occurring in the retina following monocular deprivation remain largely undescribed, despite the retina being considered as part of the nervous system based on its embryonic development from the diencephalon as well as its cellular content.

Rabbits offer a good model for vision research because they are readily available, easier to handle, and their visual capabilities as well as the cell types of its retina have been studied in detail and characterized in a fashion similar to those in humans (Amthor et al., 1989; Strettoi et al., 1994; McGillem \& Dacheux, 2001; MacNeil et al., 2004; Muraoka et al., 2012). This study therefore aimed at describing the effects of monocular deprivation on the dendritic features of the retinal ganglion cells using a rabbit model.

\section{MATERIAL AND METHOD}

\section{Study design: Non-randomized trial (Quasi experiment).}

Materials: Thirty California White (Oryctolagus cuniculus) rabbits were used. These rabbits were obtained from a local private commercial farm. The sample size was obtained using the following formula (Sakpal, 2010; Suresh \& Chandrashekara, 2012): 


$$
n=\frac{(r+1)\left(z_{(\alpha / 2)}+z_{(1-\beta)}\right)^{2} \sigma^{2}}{r \delta^{2}}
$$

Where: $\mathrm{n}=$ sample size, $\mathrm{Z}\left({ }_{1-\beta}\right)=$ desired power (typically 0.84 for $80 \%$ power), $Z_{(\mathrm{a} / 2)}=$ desired level of statistical significance (typically 1.96 for a significance of 0.05 ), $\sigma=$ standard deviation, $\delta=$ smallest meaningful difference, $r=n 1 / n 2$ is the ratio of sample size required for 2 groups (typically 1 for equal sample size for 2 groups. If $r=0.5$ gives the sample size distribution as 1:2 for 2 groups). A previous study by Muraoka et al. had revealed that the total retinal thickness of a rabbit was $194.3 \pm 7.7 \mu \mathrm{m}$. Using a statistical significance of 0.05 , power of $80 \%$, and $\delta$ of $7.7 \mathrm{~mm}$ (one standard deviation), and $r=0.5$ (ratio of controls to experimental animals of 1:2), the sample size was calculated as follows:

$n=\frac{(0.5+1)[1.96+0.84]^{2} * 7.7^{2}}{0.5 * 7.7^{2}}=\frac{1.5 * 7.84}{0.5}=23.52=24$ animals

The sample size was increased to 30 animals to cater for a $25 \%$ drop out rate.

Inclusion criteria: Since the peak period for development of ocular dominance plasticity is between the $2^{\text {nd }}$ and $4^{\text {th }}$ postnatal week, the rabbits were recruited into the study on their $14^{\text {th }}$ postnatal day.

Exclusion criteria: Rabbits with obvious congenital or acquired eye disorders were excluded from this study.

Ethical considerations: The approval to carry out the study was granted by the Biosafety, Animal Care and Use Committee of the Faculty of Veterinary Medicine, University of Nairobi-Kenya.

Handling of study animals: The rabbits were kept in wire cages measuring 4 feet by 4 feet, floored with saw dust. Each cage housed one doe and its litter, and contained a nest box where the litter stayed. Since a nursing female and its litter require a minimum floor space of 7.5 square feet (for a doe more than $5 \mathrm{~kg}$ body weight), and one doe would have 6-12 kits per litter (average 8), then a 16 square foot cage would be spacious enough for each doe and its kits. The rabbits were fed on commercial rabbit pellets, half a cup of pellets per 5 kilogram body weight daily, and were offered water ad libitum through sipper bottles with nozzles. The rabbit cages were also cleaned daily.

Monocular deprivation: Eighteen rabbits (experimental animals) were recruited on their $14^{\text {th }}$ post natal day. These rabbits were then clustered into two groups each containing eight rabbits. One group had their right eye lids sutured together while the other group had their left eye lids stitched up. These animals were restrained for body weight estimation and administration of medications using a restrain box, then anesthetized with intramuscular ketamine $(50 \mathrm{mg} / \mathrm{kg})$ and also given intramuscular analgesic (Flunixin meglumine $1.1 \mathrm{mg} / \mathrm{kg}$ ). Two drops of gentamycin (antibiotic) eye drops were applied on the eye to be deprived. The margins of the upper and lower lids of one eye were trimmed and sutured together using Nylon 5.0 single vertical mattress stitch in aseptic technique.

Following tarsorrhaphy, the rabbits were returned to their home cages and observed daily for suture breakdown or infection. Post-operative pain was managed by intramuscular Flunixin meglumine $(1.1 \mathrm{mg} / \mathrm{kg})$ every 24 hours for 4 days. In addition, the animals were clinically assessed for signs and symptoms of pain such as poor feeding, facing the back of the cage (hiding posture), vocalization by means of a piercing squeal, kicking and scratching, and teeth grinding. Rabbits that continued experiencing pain despite being on the regular analgesic received a further dose of Butorphanol $0.5 \mathrm{mg} / \mathrm{kg} \mathrm{IM} 12$ hourly until they were pain free.

Animals that developed suture dehiscence or infection were isolated from the study animals and treated accordingly. Those with suture infection received topical antibiotic eye drops (gentamycin) for five days while those with suture dehiscence were examined for any eye infection and treated with topical antibiotics.

Tissue harvesting: Three control animals were sacrificed at the start of the study (14 $4^{\text {th }}$ postnatal day). This was on the same day the experimental animals had their eyelids sutured together. Thereafter nine rabbits, 3 controls and 6 experimental, were sacrificed each successive week, as shown in Table I below. Following weight determination, the rabbits were euthanized using intravenous Euthasol ${ }^{\circledR}$ (Sodium pentobarbital $390 \mathrm{mg} / \mathrm{ml}$ + sodium phenytoin 50 $\mathrm{mg} / \mathrm{ml})$ at a dose of $1 \mathrm{~mL}$ per $4.5 \mathrm{Kg}$ body weight $(86.7$ $\mathrm{mg} / \mathrm{kg}$ pentobarbital and $11.1 \mathrm{mg} / \mathrm{kg}$ phenytoin). Once death was confirmed by loss of pupillary light reflex and corneal reflex, the thoracic cavity was opened then intra cardiac perfusion with normal saline commenced. Following perfusion, both eyes were enucleated then bisected along the vertical meridian. This was followed by removal of the vitreous humor from the eyecup so as to facilitate penetration of the fixing medium. The carcasses were incinerated after the tissues were harvested.

Tissue processing: The retinae harvested were processed for light microscopic examination. Golgi stain with Cresyl violet counterstain were used to elucidate the neuronal processes (axons and dendrites) of the ganglion neurons. 
Morphometric analysis: Photomicrographs of the sections were taken using Canon ${ }^{\circledR}$ digital camera (12 megapixels). These photographs were transferred to a computer installed with ImageJ-Fiji software (Schindelin et al., 2012) for morphometric and stereological analysis. ImageJ is open source software developed by United States National Institute of Health for processing and analyzing images. It has inbuilt morphometric and stereological tools. Using the Simple Neurite tracer plugin, the dendrites of each ganglion neuron was followed to the inner plexiform layer. Simple Neurite Tracer plugin is designed to allow for reconstruction, visualization and analysis of neuronal processes (Longair $e t$ al., 2011). The following parameters were determined as described by previous studies (Coombs et al., 2007; Germain et al., 2010; Milatovic et al., 2010) (Fig. 1):
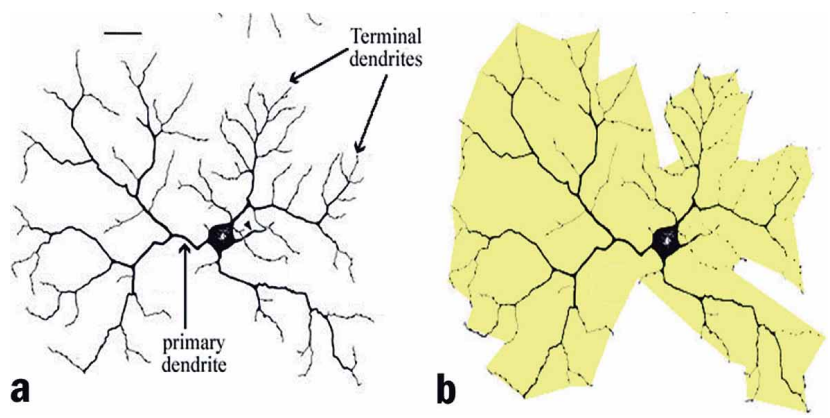

Fig. 1. Dendritic features of a neuron. a) Primary dendrites emerge directly from the cell body (soma), then divides into secondary branches that finally end as terminal branches. b) The dendritic field area is the yellow shaded area.

Number of primary dendrites: the number of dendrites emerging from the soma.

Number of terminal dendrites: the number of outermost tips of the dendrites from a single-cell.

Dendritic ramification index: number of terminal dendrites / number of primary dendrites.

Dendritic field size: area bounded by a line connecting the tips of the terminal dendrites.

Statistical analysis: Data collected were entered into the Statistical Package for Social Sciences software (Version 17.0, Chicago, Illinois) for coding, tabulation and statistical analysis. After confirming that the data was normally distributed using histograms and box plots, parametric tests were used to compare the means of the variables measured.
Analysis of Variance (ANOVA) test was used to compare the means of each variable studied from baseline to the end of third week of study. The Student's t-test was used to compare the differences in means between the non-deprived and deprived eyes, non-deprived and control eyes, and deprived and control eyes. A $p$ value $<0.05$ was considered significant at $95 \%$ confidence interval.

\section{RESULTS}

Deprived eyes. The number of the primary and terminal dendrites initially increased until the second week of deprivation thereafter decreased as duration of deprivation increased (Table II). The dendritic field area peaked at the end of one week of deprivation then rapidly reduced with further deprivation. However, one-way ANOVA analysis of these differences did not reveal any statistically significant changes.

Non-deprived eyes.There was increase in the number of both the primary and terminal dendrites with increasing deprivation (Table II), resulting in statistically significant change in the dendritic ramification index $(p=0.040)$. From the baseline, the number of primary dendrites increased by $66.7 \%(p=0.385)$, while the terminal dendrites increased by $400 \%$ ( $p=0.002$ ). The dendritic field area increased rapidly in the first week of deprivation then plateaued. However, there were no statistically significant changes in the dendritic field area with increase in deprivation time.

Control eyes. There were no statistically significant agerelated changes in the number of primary dendrites, terminal dendrites, dendritic ramification index and the dendritic field area among the control rabbits (Table II).

Comparison of the dendritic variables between nondeprived and deprived eyes. The non-deprived retinae had more primary dendrites, terminal dendrites, dendritic field area, and dendritic ramification indices compared to the deprived eyes (Fig. 2). These were more marked with increasing period of deprivation. Student's t-test revealed statistically significant differences in the terminal dendrites at the end of the $3^{\text {rd }}$ week $(p=0.039)$. This lead to statistically significant differences in the dendritic ramification indices (Table III).

Table I. Study schedule.

\begin{tabular}{lccc}
\hline Study week & \multirow{2}{*}{ n of control animals } & \multicolumn{2}{c}{ n of experimental animals } \\
& & Right eye sutured & Left eye sutured \\
\hline Week 0 (postnatal day 14) & 3 rabbits (baseline) & --- & -- \\
Week 1 (postnatal day 21) & 3 & 3 & 3 \\
Week 2 (postnatal day 28) & 3 & 3 & 3 \\
Week 3 (postnatal day 35) & 3 & 3 & 3 \\
\hline
\end{tabular}


Table II. Dendritic variables in deprived, non-deprived, and control eyes.

\begin{tabular}{lcccccc}
\hline & $\begin{array}{c}\text { Duration of } \\
\text { deprivation } \\
\text { (weeks) }\end{array}$ & \multicolumn{2}{c}{ Deprived } & \multicolumn{2}{c}{ Non-deprived } & \multicolumn{2}{c}{ Controls } \\
\hline n of primary & $\mathbf{0}$ & $1.5 \pm 0.7$ & $\mathbf{0 . 6 7 9}$ & $1.5 \pm 0.7$ & $\mathbf{0 . 3 8 5}$ & $1.5 \pm 0.7$ \\
branches & $\mathbf{1}$ & $1.9 \pm 0.2$ & & $2.3 \pm 0.5$ & & $2.0 \pm 0.7$ \\
& $\mathbf{2}$ & $2.3 \pm 0.4$ & & $2.3 \pm 0.6$ & & $2.2 \pm 0.8$ \\
& $\mathbf{3}$ & $2.3 \pm 1.0$ & & $2.5 \pm 0.7$ & & $2.4 \pm 0.5$ \\
n of & $\mathbf{0}$ & $1.5 \pm 0.7$ & $\mathbf{0 . 7 9 2}$ & $1.5 \pm 0.7$ & $\mathbf{0 . 0 0 2} *$ & $1.5 \pm 0.7$ \\
terminal & $\mathbf{1}$ & $2.5 \pm 0.7$ & & $4.3 \pm 1.3$ & & $2.5 \pm 0.7$ \\
branches & $\mathbf{2}$ & $3.0 \pm 1.4$ & & $5.3 \pm 0.6$ & & $2.8 \pm 0.8$ \\
& $\mathbf{3}$ & $2.8 \pm 2.1$ & & $7.5 \pm 0.7$ & & $3.5 \pm 0.6$ \\
Dendritic & $\mathbf{0}$ & $1.0 \pm 0.0$ & $\mathbf{0 . 8 3 4}$ & $1.0 \pm 0.0$ & $\mathbf{0 . 0 4 0} *$ & $1.0 \pm 0.0$ \\
Ramification & $\mathbf{1}$ & $1.4 \pm 0.5$ & & $1.9 \pm 0.3$ & & $1.4 \pm 0.8$ \\
Index & $\mathbf{2}$ & $1.3 \pm 0.4$ & & $2.4 \pm 0.7$ & & $1.4 \pm 0.5$ \\
& $\mathbf{3}$ & $1.1 \pm 0.5$ & & $3.2 \pm 1.2$ & & $1.6 \pm 0.5$ \\
Dendritic & $\mathbf{0}$ & $990.4 \pm 134$ & $\mathbf{0 . 8 7 8}$ & $990.4 \pm 134$ & $\mathbf{0 . 5 2 3}$ & $990.4 \pm 134.0$ \\
field area & $\mathbf{1}$ & $1213.8 \pm 253$ & & $1903.0 \pm 774.0$ & & $1053.1 \pm 37.7$ \\
$(\mu$ m 2 ) & $\mathbf{2}$ & $1020.4 \pm 120$ & & $1914.1 \pm 935.9$ & & $1059.4 \pm 319.0$ \\
& $\mathbf{3}$ & $840.6 \pm 350$ & & $1866.6 \pm 546.9$ & & $1049.6 \pm 853.9$ \\
\hline
\end{tabular}

$* \mathrm{p}<0.05$
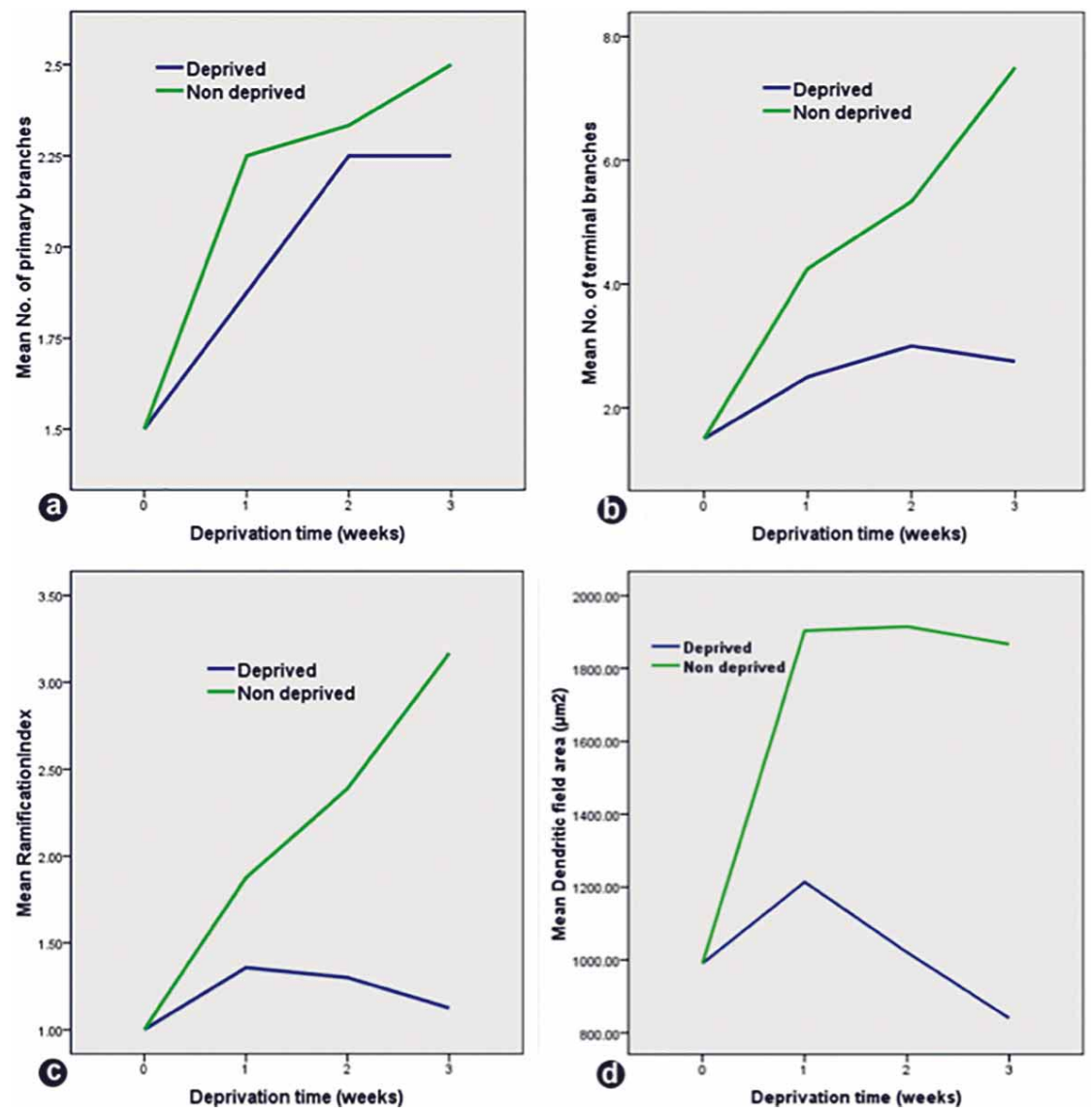

Fig. 2. Mean plots for dendritic features in the non-deprived and deprived eyes. a) Primary dendrites, b) Terminal dendrites, c) Dendritic Ramification Index, d) Dendritic field area.
Comparison of the dendritic variables between deprived and control eyes. While the dendritic features of the ganglion cells of the deprived eyes decreased with increasing deprivation, those of the control group either increased or plateaued (Fig. 3). The Student t-test analysis however did not reveal any statistically significant differences in the variables between the deprived and control animals (Table IV).

Comparison of the dendritic variables between non-deprived and control eyes. Non-deprived eyes had more primary dendrites, terminal dendrites, dendritic ramification index and dendritic field area compared to the controls (Fig. 4). However, statistically significant differences were noted in the terminal dendrites after two weeks of deprivation (Table V). The terminal dendrites in the non-deprived eyes were $90.5 \%(p=0.004)$ and $114.3 \%$ $(p=0.002)$ more compared to controls after two and three weeks of deprivation respectively. 
Table III. Comparison of dendritic variables between non-deprived and deprived eyes.

\begin{tabular}{|c|c|c|c|c|c|c|c|}
\hline & & \multicolumn{2}{|c|}{ Week One } & \multicolumn{2}{|c|}{ Week Two } & \multicolumn{2}{|c|}{ Week Three } \\
\hline & & Mean & p-value & Mean & p-value & Mean & p-value \\
\hline Primary & Deprived & 1.9 & & 2.3 & & 2.3 & \\
\hline branches & Non deprived & 2.3 & 0.383 & 2.3 & 0.900 & 2.5 & 0.765 \\
\hline Terminal & Deprived & 2.5 & 0153 & 3.0 & 0073 & 2.8 & \\
\hline branches & Non deprived & 4.3 & 0.153 & 5.3 & 0.073 & 7.5 & $0.039 *$ \\
\hline Ramification & Deprived & 1.4 & 0147 & 1.3 & 0142 & 1.1 & $0032 *$ \\
\hline Index & Non deprived & 1.9 & 0.147 & 2.4 & 0.142 & 3.2 & $0.032^{*}$ \\
\hline $\begin{array}{l}\text { Dendritic Field } \\
\text { area }\left(\mu^{2}\right)\end{array}$ & $\begin{array}{l}\text { Deprived } \\
\text { Non deprived }\end{array}$ & $\begin{array}{l}1213.8 \\
1903.0\end{array}$ & 0.373 & $\begin{array}{l}1020.4 \\
1914.1\end{array}$ & 0.290 & $\begin{array}{c}840.6 \\
1866.6\end{array}$ & 0.105 \\
\hline
\end{tabular}

$* \mathrm{p}<0.05$

Table IV. Comparison of dendritic variables between deprived and control eyes.

\begin{tabular}{|c|c|c|c|c|c|c|c|}
\hline & & \multicolumn{2}{|c|}{ Week One } & \multicolumn{2}{|c|}{ Week Two } & \multicolumn{2}{|c|}{ Week Three } \\
\hline & & Mean & p-value & Mean & p-value & Mean & p-value \\
\hline Primary & Deprived & 1.9 & & 2.3 & 0941 & 2.3 & \\
\hline branches & Control & 2.0 & 0.831 & 2.2 & 0.941 & 2.4 & 0.823 \\
\hline Terminal & Deprived & 2.5 & 1000 & 3.0 & 0817 & 2.8 & 0510 \\
\hline branches & Control & 2.5 & & 2.8 & & 3.5 & \\
\hline Ramification & Deprived & 1.4 & 0957 & 1.3 & 0829 & 1.1 & 0285 \\
\hline Index & Control & 1.4 & 0.951 & 1.4 & 0.029 & 1.6 & 0.203 \\
\hline $\begin{array}{l}\text { Dendritic Field } \\
\text { area }\left(\mu \mathrm{m}^{2}\right)\end{array}$ & $\begin{array}{l}\text { Deprived } \\
\text { Control }\end{array}$ & $\begin{array}{l}1213.8 \\
1053.1\end{array}$ & 0.815 & $\begin{array}{l}1020.4 \\
1059.4\end{array}$ & 0.879 & $\begin{array}{c}840.6 \\
1049.6\end{array}$ & 0.699 \\
\hline
\end{tabular}
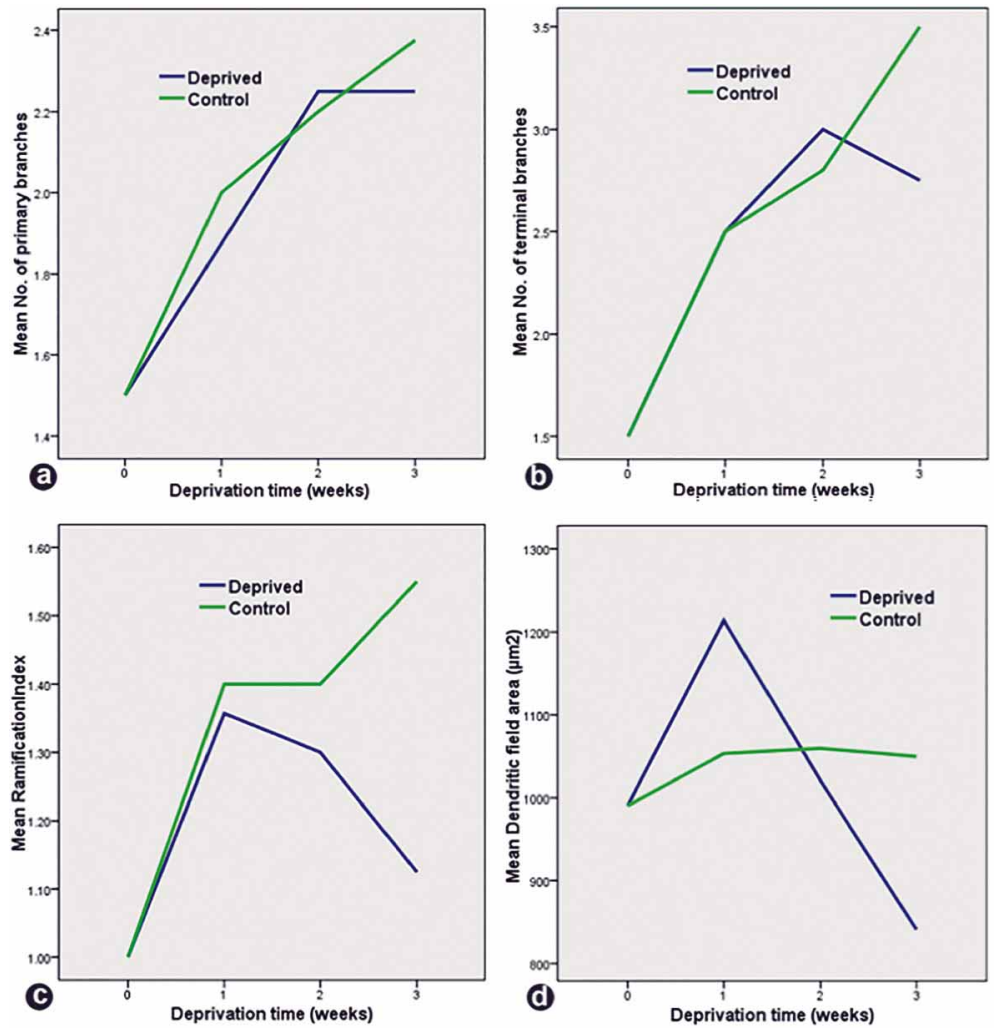

Fig. 3. Mean plots for dendritic features in the deprived and control eyes. a) Primary dendrites, b) Terminal dendrites, c) Dendritic Ramification Index, d) Dendritic field area. 

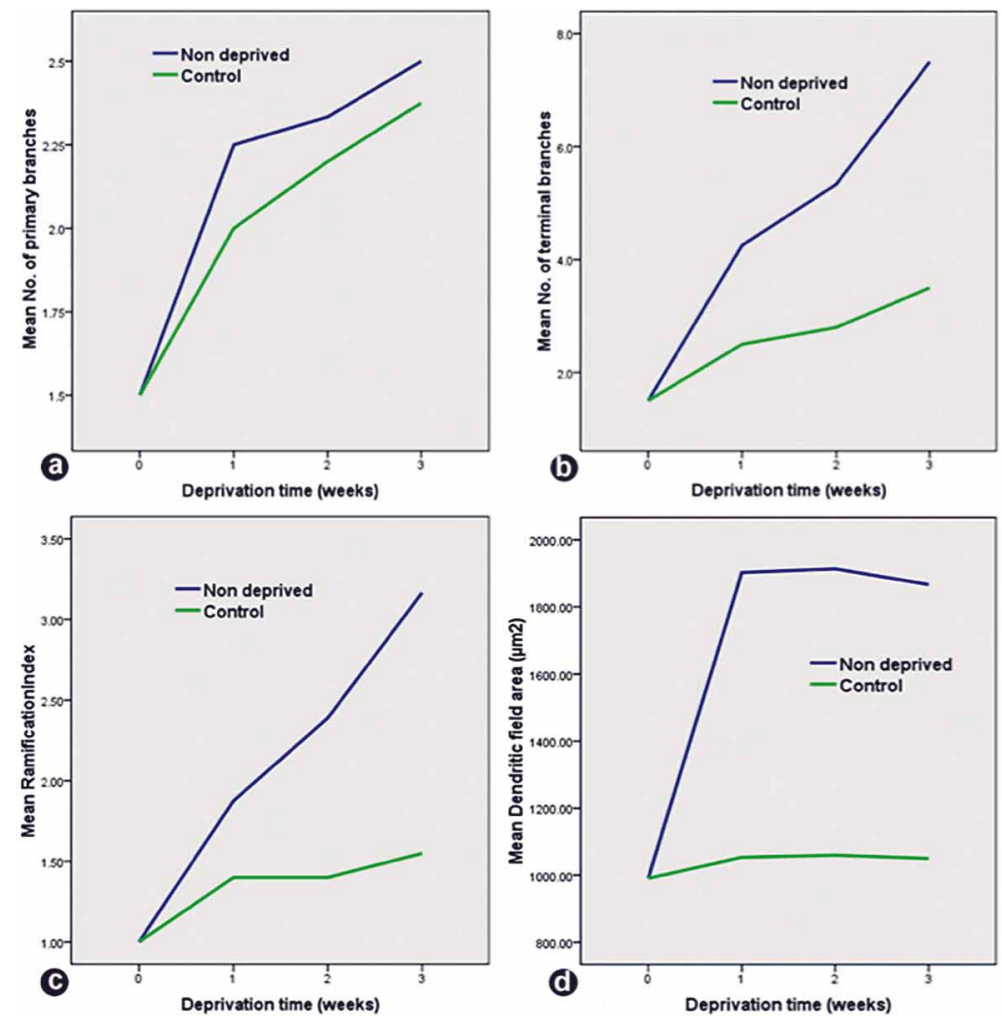

Fig. 4. Mean plots for dendritic features in the non-deprived and control eyes. a) Primary dendrites, b) Terminal dendrites, c) Dendritic Ramification Index, d) Dendritic field area.

Table V. Comparison of dendritic variables between non-deprived and control eyes.

\begin{tabular}{llcccccc}
\hline & & \multicolumn{2}{c}{ Week One } & \multicolumn{2}{c}{ Week Two } & \multicolumn{2}{c}{ Week Three } \\
\cline { 3 - 7 } & & Mean & p-value & Mean & p-value & Mean & p-value \\
\hline Primary & Non-Deprived & 2.3 & 0.633 & 2.3 & 0.818 & 2.5 & 0.804 \\
branches & Control & 2.0 & & 2.2 & & 2.4 & \\
Terminal & Non-Deprived & 4.3 & 0.153 & 5.3 & $0.004 *$ & 7.5 & $0.002 *$ \\
branches & Control & 2.5 & & 2.8 & & 3.5 & \\
Ramification & Non-Deprived & 1.9 & \multirow{2}{*}{0.314} & 2.4 & 0.062 & 3.2 & 0.066 \\
Index & Control & 1.4 & & 1.4 & & 1.6 & \\
Dendritic Field & Non-Deprived & 1903.0 & 0.217 & 1914.1 & 0.141 & 1866.6 & 0.298 \\
area $\left(\boldsymbol{\mu m}^{2}\right)$ & Control & 1053.1 & & 1059.4 & & 1049.6 & \\
\hline * $<0.05$ & & & & & & &
\end{tabular}

\section{DISCUSSION}

The ganglion cells in the non-deprived eyes in the present study had a steady increase in the number of primary and terminal branches as well as the dendritic field area with increasing duration of deprivation. Our findings concur with reports by other workers who demonstrated increased synapses in the inner plexiform layer of non-deprived eyes
(Fifková, 1972, 1973). Usually, the ganglion cell dendritogenesis begins with the extension of several primary dendrites that project out from the soma, toward the inner plexiform layer (Huberman, 2007). After initiation from the soma, the primary dendrites then branch actively, adding and retracting branches to remodel the dendritic arbor 
(Coombs et al.). The morphology of ganglion cell dendrites continues to be modified by pruning mechanisms that persist long after initial synaptic contacts are formed in the visual system (Coombs et al.; Huberman). The extent and form of the dendritic arbor is modulated within the retina by afferent input mediated through neurotransmitters produced by bipolar and amacrine cells (Cohen-Cory \& Lom, 2004). As was observed in the present study, the cell densities of the inner nuclear layer that contains bipolar and amacrine cells, had significantly increased in the non-deprived eye with increasing duration of deprivation. It is therefore plausible that the increased number of the inner nuclear cells produced more dendritogenic factors in the non-deprived eyes, leading to the increased dendritic aborisations of the ganglion cells and subsequent increase in the dendritic field area.

The deprived eyes in the present study had initial increase in the number of both primary and terminal dendrites as well as the dendritic field area before reducing after the first week of deprivation. This implies that the ganglion cells initially attempted to compensate the lack of light by increasing its synaptic contacts however with prolonged deprivation, these synapses could not be sustained therefore they were pruned. Studies have shown visual stimulation is required for refinement of the retinal ganglion synaptic contacts (Tian \& Copenhagen, 2003; Tian, 2004). Dark rearing results in initial increase in the inner plexiform layer synapses in rodents (Fisher, 1979), and turtles (Sernagor \& Grzywacz 1996) in an attempt to compensate for the lack of light, and has been associated with increased spontaneous expression of acetylcholine by the immature ganglion cells (Sernagor \& Grzywacz). Visual experience controls the later stages of retinal ganglion cell dendritogenesis, and has been shown to abolish the spontaneous acetylcholine expression in the immature ganglion cells (Tian \& Copenhagen; Tian; Cohen-Cory \& Lom). Visual experience modulates the expression of neurotrophic factors such as retinal BDNF, which is produced by the inner nuclear cells (Cohen-Cory \& Lom; Wong \& Ghosh, 2002). Thus, reduction in the number of the dendrites and dendritic field area seen with further deprivation in the present study could be as a result of reduced production of neurotrophic factors from the degenerating inner nuclear layer cells in the deprived eyes.

\section{CONCLUSION}

The present study has demonstrated that monocular deprivation results reduction in the dendrites of ganglion neurons in the deprived eyes with compensatory increase in the dendrites among the non-deprived eyes. These changes in the retina may contribute to the changes seen in the visual cortex in monocularly deprived animals. However, there is need for further studies to determine whether these changes in the retina are reversible, and if they are, then the maximum period of deprivation beyond which these changes cannot occur should be ascertained.

MWACHAKA, P.; SAIDI, H.; ODULA, P. \& MANDELA, P. Efectos de la privación monocular sobre las características dendríticas de las células ganglionares de la retina. Int. J. Morphol., 32(4):1144-1151, 2014.

RESUMEN: La privación monocular de la visión resulta en cambios anatómicos en la corteza visual en favor del ojo no privado. Aunque la retina forma parte de la vía visual, hay escasez de datos sobre el efecto de la privación monocular en su estructura. El objetivo de esta investigación fue describir los efectos de la privación monocular en las características de las dendritas de las células ganglionares de la retina. Se diseñó un estudio cuasi-experimental. Se examinaron 30 conejos (18 experimentales, 12 controles). La privación monocular se logró a través de la sutura unilateral del párpado en los animales de experimentación. Los conejos fueron observados durante tres semanas. Cada semana, 6 animales experimentales y 3 control fueron eutanasiados, donde se obtuvo la retina y fue procesada para realizar microscopía óptica. Las microfotografías de la retina fueron tomadas con una cámara digital y luego se utilizó el software FIJI para su análisis. El número de dendritas primarias, terminales y el área del campo de dendritas en los ojos no privados aumentó un $66,7 \%$ ( $\mathrm{p}=0,385), 400 \%(\mathrm{p}=0,002), \mathrm{y} 88,4 \%$ ( $\mathrm{p}=0,523)$, respectivamente. Los ojos no privados, tenían $114,3 \%$ más dendritas terminales $(\mathrm{p}=0,002)$ en comparación con los controles. Entre los ojos privados, todas las variables medidas tuvieron un aumento gradual en las dos primeras semanas, seguido de descenso con mayor privación. No se observaron diferencias estadísticamente significativas entre los ojos privados y el grupo control. En conclusion, la privación monocular produce un aumento de los contactos sinápticos en los ojos no privados, con cambios recíprocos que se manifiestan en los ojos privados de la visión.

PALABRAS CLAVE: Privación monocular; Retina; Células ganglionares de la retina; Características dendríticas; Ojo.

\section{REFERENCES}

Amthor, F. R.; Takahashi, E. S. \& Oyster, C. W. Morphologies of rabbit retinal ganglion cells with complex receptive fields. $J$. Comp. Neurol., 280(1):97-121, 1989.
Antonini, A. \& Stryker, M. P. Rapid remodeling of axonal arbors in the visual cortex. Science, 260(5115):1819-21, 1993. 
Antonini, A.; Fagiolini, M. \& Stryker, M. P. Anatomical correlates of functional plasticity in mouse visual cortex. J. Neurosci., 19(11):4388-406, 1999.

Cang, J.; Kalatsky, V. A.; Löwel, S. \& Stryker, M. P. Optical imaging of the intrinsic signal as a measure of cortical plasticity in the mouse. Vis. Neurosci., 22(5):685-91, 2005.

Cohen-Cory, Susana, and Barbara Lom. Neurotrophic regulation of retinal ganglion cell synaptic connectivity: from axons and dendrites to synapses. Int. J. Dev. Biol., 48(8-9):947-56, 2004.

Coombs, J. L.; Van Der List, D. \& Chalupa, L. M. Morphological Properties of Mouse Retinal Ganglion Cells during Postnatal Development. J. Comp. Neurol., 503(6):803-14, 2007.

Fifková, E. Effect of visual deprivation and light on synapses of the inner plexiform layer. Exp. Neurol., 35(3):458-69, 1972.

Fifková, E. Effect of light on the synaptic organization of the inner plexiform layer of the retina in albino rats. Experientia, 29(7):851-4, 1973.

Fisher, L. J. Development of retinal synaptic arrays in the inner plexiform layer of dark-reared mice. J. Embryol. Exp. Morphol., 54:219-27, 1979.

Germain, F.; Pérez-Rico, C.; Vicente, J. \& de la Villa, P. Functional Histology of the Retina. Formatex. 2010. Disponible en: http:/ /www.formatex.info/microscopy4/914-925.pdf.

Hofer, S. B.; Mrsic-Flogel, T. D.; Bonhoeffer, T. \& Hübener, M. Prior experience enhances plasticity in adult visual cortex. Nat. Neurosci., 9(1):127-32, 2006.

Huberman, A. D. Mechanisms of eye-specific visual circuit development. Curr. Opin. Neurobiol., 17(1):73-80, 2007.

Lehmann, K. \& Löwel, S. Age-dependent ocular dominance plasticity in adult mice. PloS One, 3(9):e3120, 2008.

Longair, M. H.; Baker, D. A. \& Armstrong, J. D. Simple Neurite Tracer: open source software for reconstruction, visualization and analysis of neuronal processes. Bioinformatics, 27(17):2453-4, 2011.

MacNeil, M. A.; Heussy, J. K.; Dacheux, R. F.; Raviola, E. \& Masland, R. H. The population of bipolar cells in the rabbit retina. J. Comp. Neurol., 472(1):73-86, 2004.

McGillem, G. S. \& Dacheux, R. F. Rabbit cone bipolar cells: correlation of their morphologies with whole-cell recordings. Vis. Neurosci., 18(5):675-85, 2001.

Milatovic, D.; Montine, T. J.; Zaja-Milatovic, S.; Madison, J. L.; Bowman, A. B. \& Aschner, M. Morphometric analysis in neurodegenerative disorders. Curr. Protoc. Toxicol., Chapter 12:Unit12.16, 2010.
Muraoka, Y.; Ikeda, H. O.; Nakano, N.; Hangai, M.; Toda, Y.; Okamoto-Furuta, K.; Kohda, H.; Kondo, M.; Terasaki, H.; Kakizuka, A. \& Yoshimura, N. Real-time imaging of rabbit retina with retinal degeneration by using spectral-domain optical coherence tomography. PLoS One, 7(4):e36135, 2012.

Sakpal, T. V. Sample size estimation in clinical trial. Perspect. Clin. Res., 1(2):67-9, 2010.

Schindelin, J.; Arganda-Carreras, I.; Frise, E.; Kaynig, V.; Longair, M.; Pietzsch, T.; Preibisch, S.; Rueden, C.; Saalfeld, S.; Schmid, B.; Tinevez, J. Y.; White, D. J.; Hartenstein, V.; Eliceiri, K.; Tomancak, P. \& Cardona, A. Fiji: an open-source platform for biological-image analysis. Nat. Methods, 9(7):676-82, 2012.

Sernagor, E. \& Grzywacz, N. M. Influence of spontaneous activity and visual experience on developing retinal receptive fields. Curr. Biol., 6(11):1503-8, 1996.

Strettoi, E.; Dacheux, R. F. \& Raviola, E. Cone bipolar cells as interneurons in the rod pathway of the rabbit retina. J. Comp. Neurol., 347(1):139-49, 1994.

Suresh, K. P. \& Chandrashekara, S. Sample size estimation and power analysis for clinical research studies. J. Hum. Reprod. Sci., 5(1):7-13, 2012.

Tagawa, Y.; Kanold, P. O.; Majdan, M. \& Shatz, C. J. Multiple periods of functional ocular dominance plasticity in mouse visual cortex. Nat. Neurosci., 8(3):380-8, 2005.

Tian, N. Visual experience and maturation of retinal synaptic pathways. Vision Res., 44(28):3307-16, 2004.

Tian, N. \& Copenhagen, D. R. Visual stimulation is required for refinement of $\mathrm{ON}$ and $\mathrm{OFF}$ pathways in postnatal retina. Neuron, 39(1):85-96, 2003.

Trachtenberg, J. T. \& Stryker, M. P. Rapid anatomical plasticity of horizontal connections in the developing visual cortex. $J$. Neurosci., 21(10):3476-82, 2001.

Wiesel, T. N. \& Hubel, D. H. Comparison of the effects of unilateral and bilateral eye closure on cortical unit responses in kittens. J. Neurophysiol., 28(6):1029-40, 1965.

Wong, R. O. \& Ghosh, A. Activity-dependent regulation of dendritic growth and patterning. Nat. Rev. Neurosci., 3(10):803-12, 2002.

Correspondence to:

Dr. Philip Maseghe Mwachaka

Department of Human Anatomy

University Of Nairobi

P.O. Box 30197

Nairobi

KENYA

Received: 09-06-2014

Accepted: 03-09-2014

Email: pmaseghe@gmail.com 